\title{
Foreword: fake twins
}

\section{Christian de Perthuis}

Covid-19 and $\mathrm{CO}_{2}$ are similar in many ways. It is the scientists who warn society of the risks to which these expose us. Politicians who refuse to listen to Intergovernmental Panel on Climate Change (IPCC) climate warnings are also those who deny the seriousness of the epidemic threat.

Covid-19 and $\mathrm{CO}_{2}$ have another similarity. They both threaten a global public good: public health and the climate stability. This is why it is necessary to align the behaviors of each one by tracking down the free riders to fight them effectively.

These twinning traits between Covid-19 and $\mathrm{CO}_{2}$ have clearly appeared in short-term action in the face of the pandemic. By shutting down economies, politicians have cleared the sky and reduced $\mathrm{CO}_{2}$ emissions like no other policy before. Action against health risk and action against climate change have been mutually reinforcing.

Can we draw more lasting lessons from action against the pandemic to strengthen action against global warming? I see two main ones that we will be able to implement if we take into account the differences between the action of $\mathrm{CO}_{2}$ and that of the virus, in fact two fake twins.

Firstly, the temporality of the threat is not the same. Between the time the lockdown is decided and the first results appear on the speed of the virus circulation, it takes two to three weeks. In terms of climate change, it takes two to three decades because it is the stock of greenhouse gases that warms the planet and not the annual flow of our emissions.

There would be no sense in wanting to prolong the rationing mechanisms that have reduced $\mathrm{CO}_{2}$ emissions over several decades. But the economist has, in his toolbox, an instrument to achieve the results of rationing while maintaining the flexibility required for the economy to run efficiently: Emissions Trading Schemes (ETS). This is why all avenues for strengthening these mechanisms must be explored, particularly in Europe where ETS has suffered numerous dysfunctions in the past and in China where it will begin to be implemented at the national level from 2021. 
Secondly, the virus is not a human production. It has been transmitted from the animal world, following a path still unidentified, but certainly favored by our lifestyles and the way we treat nature. To combat this circulation, science is enabling the development of vaccines that will become essential weapons in action.

When it comes to warming, there will be no vaccine. For a basic reason: the pathogen is none other than ourselves since the excess $\mathrm{CO}_{2}$ in the atmosphere is of human origin. In reality, we will need to be vaccinated against ourselves, by radically modifying our ways of producing and consuming. Here again, carbon taxation seems the best instrument to trigger these increasingly urgent changes in view of the climate emergency.

This is why the pricing of carbon, via taxes or ETS, is an even more important issue in the era of the pandemic. I therefore have great pleasure in introducing this book which sheds multiple lights on these questions and shows us that the health crisis has in no way altered the dynamism and creativity of the network of researchers, policymakers, and international organizations that has formed over the years to work on environmental taxation.

Christian de Perthuis Professor at Université Paris Dauphine - PSL Founder of the Climate Economics Chair Paris, France 
Hope Ashiabor, Janet E. Milne, and Mikael Skou Andersen - 9781800888517 Downloaded from PubFactory at 04/26/2023 12:06:27PM via free access 